\title{
POTENTIAL MOBILIZATION OF INORGANIC CONTAMINANTS IN A FRENCH HARBOR SEDIMENT
}

\author{
Vincent Chatain $^{1, *}$, Cécile Delolme ${ }^{2}$, Daniel Borschneck ${ }^{3}$, Nicolas Giroud ${ }^{1,4}$, Laurent \\ Thévenin $^{2}$, Marie Loustau-Cazalet ${ }^{1}$, Denise Blanc ${ }^{1}$ \\ ${ }^{1}$ Université de Lyon, INSA-Lyon, Laboratoire de Génie Civil et d'Ingénierie Environnementale \\ LGCIE, 20 avenue Albert Einstein, F-69621 Villeurbanne Cedex, France \\ ${ }^{2}$ Ecole Nationale des travaux Publics de l'Etat, Laboratoire des Sciences de l'Environnement \\ LSE, rue Maurice Audin, F-69518 Vaulx-en-Velin, France. \\ ${ }^{3}$ Aix-Marseille Université - CNRS, Centre Européen de Recherche et d'Enseignement des \\ Géosciences de l'Environnement \\ CEREGE, Europôle Méditerranéen de l'Arbois BP 80, F-13545 Aix-en-Provence Cedex 4, France. \\ ${ }^{4}$ Present address: Université de Haute Alsace, Laboratoire de Gestion des Risques et Environnement \\ LGRE, 20 rue de Chemnitz, F-68200 Mulhouse, France
}

*Corresponding author: Fax: +33 (0)4 72438717 - E-mail: Vincent.Chatain@ insa-lyon.fr

\section{RESUME}

Dans la cadre d'un PRogramme de recherche sur les ECOtechnologies et le Développement Durable (PRECODD) financé par l'Agence Nationale de la Recherche (ANR) et intitulé "SEDiGEST" (GESTion durable des SEDiments de dragages des ports), les travaux présentés dans ce papier concernent plus particulièrement l'évaluation physico-chimique de la mobilisation potentielle des polluants inorganiques présents dans une matrice sédimentaire.

Dans cet objectif, une méthodologie, basée sur l'utilisation de tests de lixiviation et complétée par des analyses minéralogiques et texturales, a été développée et appliquée sur un sédiment fin sablo-argileux riche en matière organique (environ 12\%) dragué dans un port français. L'analyse minérale multiélémentaire a tout d'abord montré que ce sédiment présentait des teneurs importantes, principalement en calcium $\left(109000 \mathrm{mg} \cdot \mathrm{kg}^{-1}\right)$, fer $\left(32170 \mathrm{mg} \cdot \mathrm{kg}^{-1}\right)$, et soufre (19 $\left.660 \mathrm{mg} \cdot \mathrm{kg}^{-1}\right)$; ainsi qu'en zinc (2 $\left.120 \mathrm{mg} \cdot \mathrm{kg}^{-1}\right)$, cuivre $\left(1730 \mathrm{mg} \cdot \mathrm{kg}^{-1}\right)$, plomb (860 mg.kg $\left.{ }^{-1}\right)$.

Les principaux résultats obtenus permettent ainsi de répondre qualitativement à la question du risque de mobilisation des polluants cibles minéraux ( $\mathrm{As}, \mathrm{Cu}, \mathrm{Pb}$ et $\mathrm{Zn}$ ) présents dans cette matrice. Ce risque de mobilisation lors d'un contact à l'eau est très faible (moins de $0,1 \%$ du contenu total), du fait d'une part, du pH neutre à légèrement basique de la solution de sédiment dans ces conditions dites «naturelles», et du fait d'autre part de la stabilité de l'immobilisation de ces polluants sur les constituants des sédiments tels que la matière organique, les carbonates et/ou les sulfures. Un risque de mobilisation à plus ou moins long terme existe cependant dans des conditions de lixiviation particulières $(\mathrm{pH}<6$, présence d'un chélatant, etc.), pouvant notamment survenir dans le cadre d'un scénario de gestion de sédiments marins. 


\begin{abstract}
As part of a French national research program called "SEDiGEST" concerning the management and the environmental risk assessment of contaminated marine harbor sediments, the research presented in this paper focuses on the determination of the leachability of inorganic contaminants.

In this objective, a methodology was developed and applied to investigate the mobility of inorganic contaminants as a function of physicochemical conditions. This methodology is based on the use of leaching tests in conjunction with mineralogical and textural analysis. Muddy sediment with important Organic Matter (OM) content (ca. $12 \mathrm{wt} \%$ ) has been selected and collected from a French harbor. This sediment contained also ca. $109000 \mathrm{mg} \cdot \mathrm{kg}^{-1}$ calcium (Ca), ca. $32170 \mathrm{mg} \cdot \mathrm{kg}^{-1}$ iron (Fe), ca. $19660 \mathrm{mg} \cdot \mathrm{kg}^{-1}$ sulfur (S), ca. $2120 \mathrm{mg} \cdot \mathrm{kg}^{-1}$ zinc (Zn), ca. $1730 \mathrm{mg} \cdot \mathrm{kg}^{-1}$ copper $(\mathrm{Cu})$, ca. $860 \mathrm{mg} \cdot \mathrm{kg}^{-1}$ lead $(\mathrm{Pb})$ and ca. $150 \mathrm{mg} \cdot \mathrm{kg}^{-1}$ arsenic (As). In addition, this sediment had a natural $\mathrm{pH}$ and ORP (Oxidation Reduction Potential) of $c a .8 .2$ and ca. $+350 \mathrm{mV}$ vs. Normal Hydrogen Electrode (NHE).

Main results shown in this study indicate that the release of target contaminants ( $\mathrm{As}, \mathrm{Cu}, \mathrm{Pb}$ and $\mathrm{Zn}$ ) during a contact with deionized water is very limited ( $c a$. $<-0.1 \mathrm{wt} \%$ ) by the very low solubility of solids, like sulfides or carbonated phases, and by the stability of their bearing solid phases (i.e., OM and/or sulfides) at natural slightly basic conditions. However, the natural $\mathrm{pH}$ of this matrix can vary with the loose of the buffering capacity and an increased mobilization is observed over the long term under specific leaching conditions (i.e., $\mathrm{pH}<6$, or chelation effect, etc.) which can arise in a given scenario for the management of marine sediments.
\end{abstract}

\title{
1. INTRODUCTION
}

The French national research agency (ANR) initiated a three years program called "SEDiGEST", concerning the management and the environmental risk assessment of contaminated marine harbor sediments. As part of this program, the research presented in this paper focuses on the determination of the leachability of inorganic contaminants. In this objective, a methodology was developed and applied to investigate the potential mobilization of inorganic contaminants [1-2]. This methodology, based on the use of leaching tests in conjunction with mineralogical and textural analysis, was firstly applied to an untreated French harbor sediment.

Therefore, the research presented here provides data concerning the solubility and mobility of inorganic contaminants ( $\mathrm{As}, \mathrm{Cu}, \mathrm{Pb}$ and $\mathrm{Zn}$ ) in this selected matrix as a function of the sediment composition and physicochemical conditions.

\section{MATERIALS AND METHODS}

\subsection{Sediment sample collection and preparation}

Raw sediment from a French harbor was used for the study. Prior to characterization and liquid-solid partitioning experiments, the matrix was sieved at $2 \mathrm{~mm}$, homogenized, and stored at $4^{\circ} \mathrm{C}$ in the dark.

\subsection{Physical and chemical characterization of the sediment}

The structural characteristics were analyzed with a Grain size analyses by a laser diffractometer (a Malvern mastersizer $2000 \mathrm{G}^{\circledR}$ ) with a range from $0.02 \mu \mathrm{m}$ to $1000 \mu \mathrm{m}$. The non-aggregation of the sediment was previously checked. It was then 
decided to fractionate the sediment into four particle size fractions (respectively, 630-1000 $\mu \mathrm{m}, 63-630 \mu \mathrm{m}, 10-63 \mu \mathrm{m}$ and $<10 \mu \mathrm{m}$ ).

Total content of trace elements and major constituents was determined by acid digestion [3] and subsequent analyses using Inductively Coupled Plasma Atomic Emission Spectrometry (ICP-AES, Jobin-Yvon Ultima $2^{\circledR}$ ) in the sediment and the fractionated fractions.

X-Ray Diffraction (XRD, Panalytical X'Pert Pro MPD diffractometer) was also used in conjunction with single $[1-2 ; 4-5]$ and sequential chemical extraction techniques [6-7]. Single extraction techniques using deionized water and $0.05 \mathrm{M}$ EDTA solution at $\mathrm{pH} 7$ were performed to determine, respectively, the soluble and available fractions in the sediment [2; 4-5]. These single extractions were carried out in triplicate using an $\mathrm{L} / \mathrm{S}$ ratio of $10 \mathrm{~mL} / \mathrm{g}$ and a contact time of 48 hours, except for the EDTA extraction for which an L/S ratio of $100 \mathrm{~mL} / \mathrm{g}$ was used. Additionally, a sequential chemical extraction procedure adapted from Tessier al. (1979) and Quevauviller et al. (1997) [6-7] was carried out in triplicate to determine the, operationally defined, distribution of four fractions: acid-extractable (0.11 M HOAc), reducible $\left(0.5 \mathrm{M} \mathrm{NH}_{4} \mathrm{OH} \cdot \mathrm{Cl}\right.$ adjusted to $\left.\mathrm{pH} 2\right)$, oxidizable $\left(8.8 \mathrm{M} \mathrm{H}_{2} \mathrm{O}_{2}\right.$ adjusted to $\mathrm{pH} 2$ at $90^{\circ} \mathrm{C}$ followed by $1 \mathrm{M} \mathrm{NH} \mathrm{NH}_{4} \mathrm{OAc}$ adjusted to $\mathrm{pH} 2$ ) and residual fractions (estimated from the total content obtained using acid digestion); for constituents of interest in the sediment.

Finally, liquid-solid partitioning of elements of interest was determined at varying $\mathrm{pH}$. Thirteen subsamples of sediment were suspended in triplicate during 48 hours with solutions of varying equivalents of $\mathrm{HNO}_{3}$ or $\mathrm{NaOH}$ at an $\mathrm{L} / \mathrm{S}$ ratio of $10 \mathrm{~mL} / \mathrm{g}$ to reach final $\mathrm{pHs}$ ranging between 1 and 13 (SR002.1 protocol, Solubility and Release as a function of $\mathrm{pH}[1])$.

All leachates obtained were filtered through $0.45 \mu \mathrm{m}$ pore size acetate-cellulose Whatman ${ }^{\circledR}$ membranes, and subsequently analyzed for concentrations of constituents of interest using ICP-AES. Sulfates and chlorides were analyzed using IC (ion chromatography, Dionex DX320 HPIC ${ }^{\circledR}$ ). Total Organic Carbon (TOC) in solution was measured using TOC analyzer (Total Organic Carbon analyzer, Shimadzu TOC$\left.5000 \mathrm{~A}^{\circledR}\right)$.

\section{RESULTS AND DISCUSSION}

\subsection{Sediment sample characterization}

Results of the physical fractionation tend to show that this raw sediment was relatively fine and silty, with about $80 \%$ of particles with a diameter less than $60 \mu \mathrm{m}$.

Total content of trace elements indicated that this raw sediment contained mainly ca. 109000 mg. $\mathrm{kg}^{-1}$ Ca, ca. $32170 \mathrm{mg} \cdot \mathrm{kg}^{-1} \mathrm{Fe}, \quad$ ca. $19660 \mathrm{mg} \cdot \mathrm{kg}^{-1} \mathrm{~S}, \quad c a$. $2120 \mathrm{mg} \cdot \mathrm{kg}^{-1} \mathrm{Zn}$, ca. $1730 \mathrm{mg} \cdot \mathrm{kg}^{-1} \mathrm{Cu}$, ca. $860 \mathrm{mg} \cdot \mathrm{kg}^{-1} \mathrm{~Pb}$ and ca. $150 \mathrm{mg} \cdot \mathrm{kg}^{-1} \mathrm{As}$. Moreover, it was characterized by a very high moisture content of $c a .61 .5 \%$, and an important $\mathrm{OM}$ content ( $\mathrm{ca} .12 \mathrm{wt} \%)$. The fractionation revealed that the finer fractions $(<63 \mu \mathrm{m})$ were more concentrated with OM, major mineral elements like magnesium $(\mathrm{Mg})$, aluminum $(\mathrm{Al}), \mathrm{Fe}$, potassium $(\mathrm{K}), \mathrm{S}$ and $\mathrm{Ca}$. Nevertheless, the heavy metal content was not significantly different in all the fractions even in the sandy ones.

Depending on particle size fractions, XRD analyses indicated the presence of quartz, feldspars, analcime, pyroxenes, gypsum, halite, chlorite, muscovite, calcite, dolomite, aragonite and pyrite. 


\subsection{Determination of the soluble and available fractions by single extractions}

After 48 hours of contact with deionized water at a L/S ratio of $10 \mathrm{~mL} / \mathrm{g}$, the sediment solution presented a natural $\mathrm{pH}$ of 8.2 and an ORP of $+350 \mathrm{mV}$ (vs. NHE). Very low soluble $(c a .<0.1 \mathrm{wt} \%)$ fractions of inorganic contaminants were obtained at these natural conditions. In contrast, a significant available fraction of $\mathrm{Pb}$ and $\mathrm{Zn}$ was observed from the single extraction using EDTA ( $c a .90 \mathrm{wt} \%$ and $80 \mathrm{wt} \%$, respectively). An important available fraction of $\mathrm{As}, \mathrm{Cu}$ and $\mathrm{Fe}$ was also measured from this extraction ( $\mathrm{ca} .40 \mathrm{wt} \%)$.

\subsection{Fractionation by a sequential extraction procedure}

Results from the sequential extraction procedure indicated that $\mathrm{Cu}$ and $\mathrm{Zn}$ were fairly mobile. About $\mathrm{ca}$. $85 \%$ and $100 \%$ of the total content in $\mathrm{Cu}$ and $\mathrm{Zn}$, respectively, were extracted within the first three extracts. These results indicated that most of the $\mathrm{Cu}$ and $\mathrm{Zn}$ was probably bound onto oxidizable fraction (i.e., sulfides or organic matter) which is consistent with results from the XRD study, and with what is generally observed [8-11]. On the opposite, $\mathrm{Pb}, \mathrm{Fe}$ and particularly As appeared essentially bound to the residual fraction (i.e., silicates, or resistant OM and sulfides), suggesting a relatively low mobility of these elements.

\subsection{Solubility and Release as a function of $\mathrm{pH}$}

Batch equilibrium leaching tests following the SR002.1 protocol [1] showed a very high buffering capacity of this sediment for $\mathrm{pH}$ values around 6 . The important size of the buffering step is consistent with results from the XRD study (i.e., carbonate minerals observed) and explained by the origin of the sediment (i.e., marine environment with fragments of seashells).

Figure 1. $\mathrm{Cu}, \mathrm{Zn}$ (A.) and As (B.) solubilization as a function of pH (contact time: 48 hours).
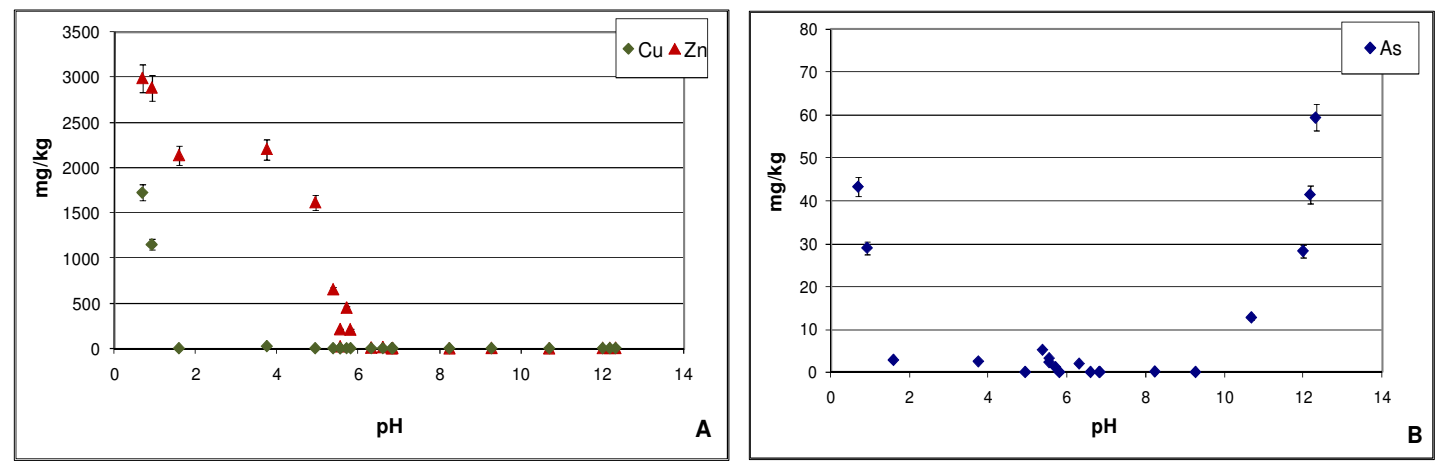

The liquid-solid partitioning of $\mathrm{Cu}, \mathrm{Zn}$ and $\mathrm{As}$ at varying $\mathrm{pH}$ is shown in Figures $1 \mathrm{~A}$ and $1 \mathrm{~B}$. Results of $\mathrm{Zn}$ and $\mathrm{Cu}$ solubilization as a function of $\mathrm{pH}$ (Figure 1A) indicated that the solubility of $\mathrm{Zn}$ and $\mathrm{Cu}$ remained very low for $\mathrm{pH}$ values above 6 and 2, respectively; and significantly increased for $\mathrm{pH}$ below these values. Results of As solubilization as a function of $\mathrm{pH}$ (Figure 1B) indicated that the solubility of As remained very low for $\mathrm{pH}$ values ranging from 2 to 11 , and significantly increased for $\mathrm{pH}$ values below 2 and above 11 .

\section{CONCLUSION}

Main results shown in this study indicate that the release of target contaminants ( $\mathrm{As}, \mathrm{Cu}, \mathrm{Pb}$ and $\mathrm{Zn}$ ) during a contact with deionized water is very limited by their 
very low solubility in the sediment solution and by the stability of their bearing solid phases (sulfide phases and/or OM) at natural slightly basic conditions.

However, the natural $\mathrm{pH}$ of this matrix appears unstable and an increased mobilization is observed over the long term under specific leaching conditions (i.e., $\mathrm{pH}$ or ORP gradient, chelation effect, etc.) which can arise in a given scenario for the management of marine sediments.

\section{ACKNOWLEDGEMENTS}

The research presented in this paper was supported by the French national research agency (ANR, France - Research program: "SEDiGEST"). The authors are grateful to EEDEMS (French research network on waste and polluted materials management) for experimental support.

\section{REFERENCES}

[1] D.S. Kosson, H.A. van der Sloot, F. Sanchez, A.C. Garrabrants, An Integrated Framework for Evaluating Leaching in Waste Management and Utilization of Secondary Materials, Environ. Eng. Sci. 19 (2002) 159-204.

[2] V. Chatain, F. Sanchez, R. Bayard, P. Moszkowicz, Arsenic behavior in mining soil, J. Phys. IV. 107 (2003) 289-292.

[3] Association Française de NORmalisation (AFNOR), Qualité des sols - Sols, sédiments - Mise en solution totale par attaque acide, NF X31-147, AFNOR Editions, Paris (France), 1996.

[4] A.C. Garrabrants, D.S. Kosson, Use of a chelating agent to determine the metal availability for leaching from soils and wastes, Waste Manage. 20 (2000) 155-165.

[5] S.K. Gupta, M.K. Vollmer, R. Krebs, The importance of mobile, mobilisable and pseudo total heavy metal fractions in soil for three-level risk assessment and risk management, Sci. Total Environ. 178 (1996) 11-20.

[6] A. Tessier, P.G.C. Campbell and M. Bisson, Sequential extraction procedure for the speciation of particulated metals, Anal. Chem. 51 (1979) 844-851.

[7] P. Quevauviller, G. Rauret, J.-F. López-Sánchez, R. Rubio, A. Ure, H. Muntau, Certification of trace metal extractable contents in a sediment reference material (CRM 601) following a three-step sequential extraction procedure, Sci. Total Environ. 205 (1997) 223-234.

[8] E.W. Brennan and W.L. Lindsay, The role of pyrite in controlling metal ion activities in highly reduced soils, Geochim. Cosmochim. Acta 60 (1996) 3609-3618. [9] C. Le Guern, P. Conil, B. Clozel, M. Albrecht, D. Levacher, N. Proulhac, C. Schwartz, P. Baticle, Aide à la gestion alternative au rejet en mer de sédiments contaminés provenant du dragage de sites portuaires - Rapport final BRGM/RP53470-FR, BRGM Editions, Orléans (France), 2004.

[10] C. Caplat, H. Texier, D. Barillier, C. Lelievre, Heavy metals mobility in harbour contaminated sediments: The case of Port-en-Bessin, Mar. Poll. Bull. 50 (2005) 50451.

[11] J. Usero, M. Gamero, J. Morillo, I.Gracia, Comparative study of three sequential extraction procedures for metals in marine sediments, Environ. Int. 24 (1998) 487496. 